\title{
The Impact of the Host Country Corruption on Inward FDI
}

\author{
Māris Sprinǵis \\ University of Latvia, Riga, Latvia
}

\begin{abstract}
Globalization creates investment opportunities for enterprises worldwide. FDI is one of the traditional options to expand into international markets. According to Dunning's ownership, location, and internationalization paradigm FDI location is driven by the search for markets, resources, efficiency, and strategic assets. Corruption can be considered as a significant factor of the attractiveness of a location and can affect also other OLI conditions. Most of the theoretical literature as well as case study and microeconomic evidence support the notion that corruption negatively impacts inward FDI flows and growth. However the macroeconomic evidence is not so unambiguous. Some macro-studies do not detect any significant negative relationship between corruption and FDI. The aim of the paper is to analyze the relationship mechanism between corruption and FDI and to evaluate the impact of the host country corruption on inward FDI flows. The results of the empiric analysis presented in the paper provide evidence of the significant negative impact of host country corruption on inward FDI. One of the main benefits from the decrease of corruption level is quantitatively valued as an additional inward flow of the foreign capital in the economy. The econometric analysis is based on panel dataset that includes data for 178 economies during the period of 2004 to 2009. The Transparency International Corruption Perceptions Index is used as a proxy for host country corruption level.
\end{abstract}

Keywords: corruption, FDI, growth

\section{Introduction}

During the last 2-3 decades, economists have paid a lot of attention to empirical research of international capital flow processes. Modeling of foreign direct investment process can be considered as a very complicated process as there are many factors which influence FDI flows. Facts which are found in the special literature can be divided into two main groups. The first group represents macroeconomic factors:

- Government policy factors, such as tax policy, commerce policy, monetary policy, etc.;

- Business cycle factors, such as GDP growth, growth of exports, etc.;

- Factors which determine development trend of the world economy, such as economic growth in other countries, stability of political and economical situation in potential investment host country, etc..

Māris Springis, Ph.D., Lecturer, Faculty of Economics and Management, University of Latvia.

Correspondence to this article should be addressed to Māris Springis, Faculty of Economics and Management, University of Latvia, Aspazijas Boulevard 5, Riga, LV-1050, Latvia. E-mail: mspringis@yahoo.com. 
The second group includes microeconomic factors:

- Specific advantages or factors which ensure company's monopoly in the market, such as product differentiation, market experience, technology and experience in business, economies on production scale;

- Factors which reduce production costs, such as economies on production scale and standardization of production;

- Factors of comparable advantages, such as an opportunity to be closer to an end user, availability of cheap production resources (labor, raw materials, etc.), accession to technological know-how and transaction cost factors;

- Diversification factors, such as differences in interest rates, differences in risk and market factors (costs, barriers, etc.).

Another factor that influences international capital flows and which has been thoroughly studied over the last 2-3 decades is the host country corruption level.

Decisions by foreign investors to undertake FDI are usually complex since they involve strategic decisions. One of the most widely accepted theory of FDI is the eclectic approach ("paradigm") developed by Dunning (1981). For a foreign investor that seeks to maximize the value of the firm, FDI is attractive if the so-called OLI conditions are met, referring to ownership, location and internalization. First, there must be an ownership advantage for the multinational relative to ownership by local firms. This may have something to do with specific technological or organizational knowledge of the multinational, but could also relate to tax issues. Second, it must be attractive for the multinational to produce abroad because of some comparative locational advantages. Otherwise, the multinational would have chosen to export, rather than to invest. Finally, it should be attractive to undertake activities within the multinational, rather than buying or leasing them from other firms (Aidt, Dutta, \& Sena, 2008).

Corruption can affect all three OLI conditions. For example, it can affect the administrative treatment of a foreign firm, relative to domestically owned firms. The level of the host country corruption as well as many other factors (e.g., taxes, infrastructure, proximity to markets, availability of qualified labor force etc.) can also be a factor that determines the attractiveness of a location for undertaking investments. The aim of the paper is to analyze the relationship mechanism between corruption and FDI and to evaluate the impact of the host country corruption on inward FDI flows.

\section{Corruption and FDI: Short Review of Theory and Empirical Evidence}

Most of the theoretical literature as well as case study and microeconomic evidence support the notion that corruption negatively impacts inward FDI flows and economic growth. Mauro (1996) noted that in the presence of corruption, entrepreneurs are aware that a portion of the proceeds from their investments may be claimed by corrupt officials. Payment of bribes is often required up front if the necessary permits are to be issued. Therefore, corruption increases uncertainty and may act as a "tax" on FDI. Extra costs in the form of bribes in order to get licenses or government permits to conduct investment raise the total costs of investment and consequently decrease the expected profitability. Many other economists including Murphy, Shleifer, and Vishny (1991, 1993), Choi and Thum (1998), Svensson (2003), Aidt, Dutta, and Sena (2008) and others also conclude that corruption has a negative impact on investment and growth. 
Figure 1 reflects the conceptual framework of so-called investment channel through which the negative impact of corruption on growth materializes: corruption as a significant risk factor adversely affects the investment behavior of entrepreneurs (they are investing less or not investing at all), which in turn leads to the slower economic growth.

Mauro (1995) provides tentative empirical evidence that corruption lowers investment and economic growth. The magnitudes of these effects are considerable: a one-standard-deviation improvement in corruption indices drawn from Business International (BI) causes investment to rise by 5 percent of GDP and the annual per capita GDP growth rate to rise by half a percentage point.

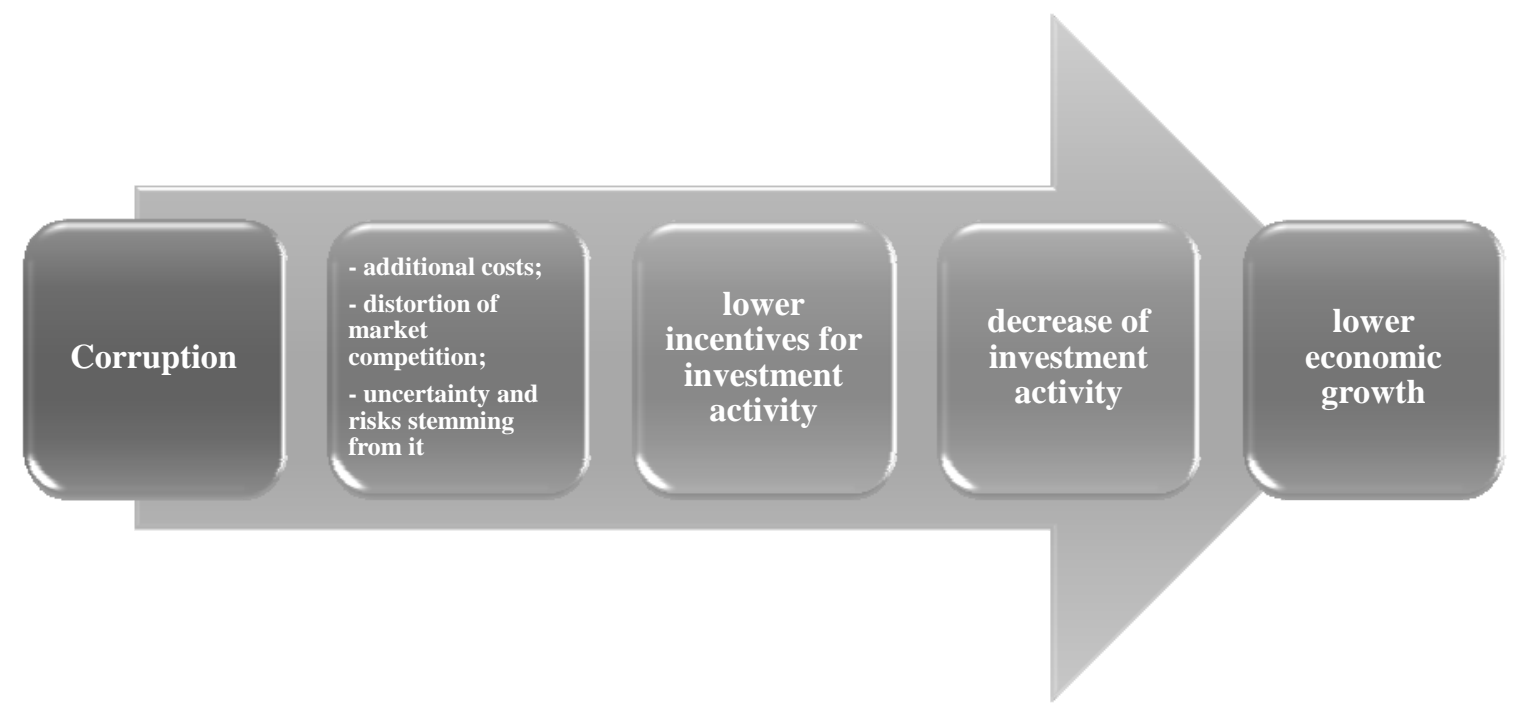

Figure 1. The impact of corruption on investment activity and economic growth. Source: Author compilation.

The evidence seems to suggest that a large portion of the effects on economic growth takes place through the effects on investment. Using indices from the International Country Risk Guide (ICRG), Keefer and Knack (1995) obtain broadly similar results and, in their estimates, institutional variables have a significant direct effect on growth in addition to the indirect effect through investment. However it should be noted that the macroeconomic evidence on the impact of host country corruption on investment and economic growth is not so unambiguous. Some macro-studies do not detect any significant negative relationship between corruption and FDI. One of the possible reasons for the mismatch between micro- and macro- evidence can be the difficulties in measuring corruption in a cross-country setting.

Some experts note that there are relatively small number of studies, which are devoted to the estimation of impact of host country corruption on inward FDI flows (Dahlstrom \& Johnson, 2007; Javorcik \& Wei, 2009). Moreover the results of these studies provide ambiguous results. Mody and Wheeler (1992) in their study on the impact of corruption on inward FDI flows in the U.S. economy have not found any statistically significant effect. Similarly, Hines (1995) finds no significant negative impact of corruption on inward FDI in a host country economy. However, Hines found that inward FDI flow growth rates in highly corrupted countries declined after the anti-corruption legislative changes (introducing criminal penalties) entered into force. By contrast, Henisz (2002) analyzing U.S. multi-national corporations (MNC) microdata, finds surprising evidence that corruption increases the inward FDI in a host country. 
However, there are also studies that provide evidence that host country corruption reduces inward FDI flows. Smarzynska and Wei (2000) using micro-data on foreign investors' business activities in Eastern Europe and former USSR countries found that corruption in the host country reduces the probability of FDI inflows. Wei (2000) using the data on three different indexes of corruption also concludes that corruption has a statistically significant negative impact on inward FDI flows. Wei draws attention to the interrelationships between corruption and the structure of inflows of foreign capital and finds that corruption significantly reduces FDI, as corruption distorts the structure of the total foreign capital inflow by reducing the share of FDI in it.

Scandinavian experts studying the MNC data in Sweden derive similar conclusions (Hakkala, Norback, \& Svaleryd, 2005). However, it should be noted that they also find that the effect of corruption is asymmetric. Corruption lowers the sales of MNCs subsidiaries in a host country market because the increase in costs for local business is not as great as for subsidiaries of MNCs because of corruption. However corruption increases their exports to the MNCs home countries as corruption can help to reduce taxes or administrative and regulatory costs.

\section{Corruption and FDI: Recent Patterns}

One of the most popular and internationally accepted measures of the level of corruption is Transparency International's Corruption Perceptions Index (CPI). The CPI ranks almost 200 countries by their perceived levels of corruption, as determined by expert assessments and opinion surveys. Figure 2 illustrates the changes in the level of corruption (the dynamics of CPI) in recent years in Baltic States and some other countries (some of which are also major investors in Latvia). Obviously, the unquestioned leader in the fight against corruption in Baltic States is Estonia. CPI values for Latvia and Lithuania are lower (indicating the higher level of corruption in comparison to Estonia) and both are at comparable levels. It should be noted, however, that Latvian CPI during the crisis period is on negative trend which indicates the growing level of corruption despite government's efforts to combat it. On the contrary Lithuania's CPI is growing since 2008.

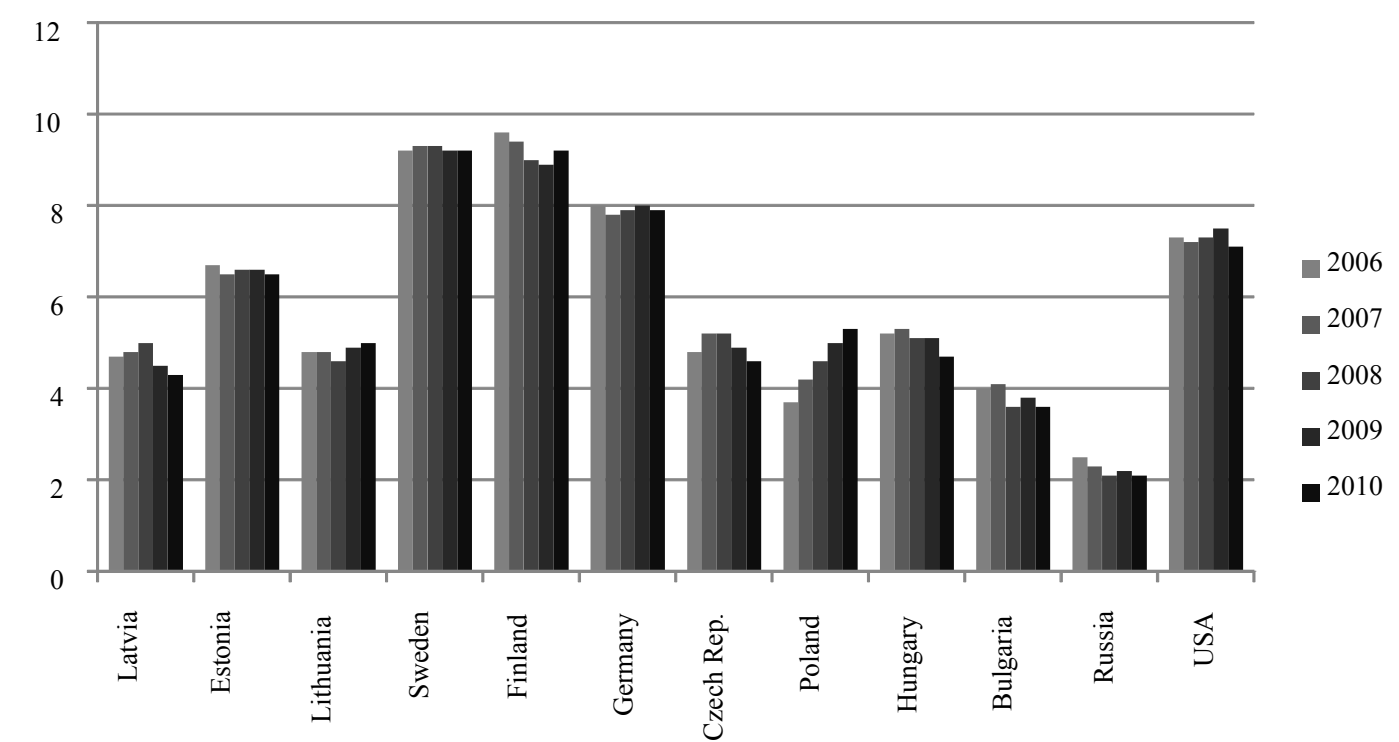

Figure 2. CPI dynamics in Baltic countries and other selected countries (2006-2010). Source: Transparency International. 
Traditionally the lowest levels of corruption worldwide are in Scandinavian countries, which are among the major investors in the Baltic region. During the recent years, Sweden and Finland are consistently in the top positions of Transparency International CPI ratings. Definitely the changes in the level of corruption affect investor activity in the above-mentioned countries. Figure 3 illustrates the dynamics of annual net inward FDI flows in recent years in Baltic States and other regions.

Investment activity in Europe and other regions has been severely affected by the recent global economic crisis. And now its recovery is seriously threatened by the growing corruption risks. Inward FDI flows in 2008-2009 in the Baltic countries were significantly lower compared to the pre-crisis levels. Of course it was not just the change in the level of corruption, but also a number of other factors which determined the dynamics of FDI flows.

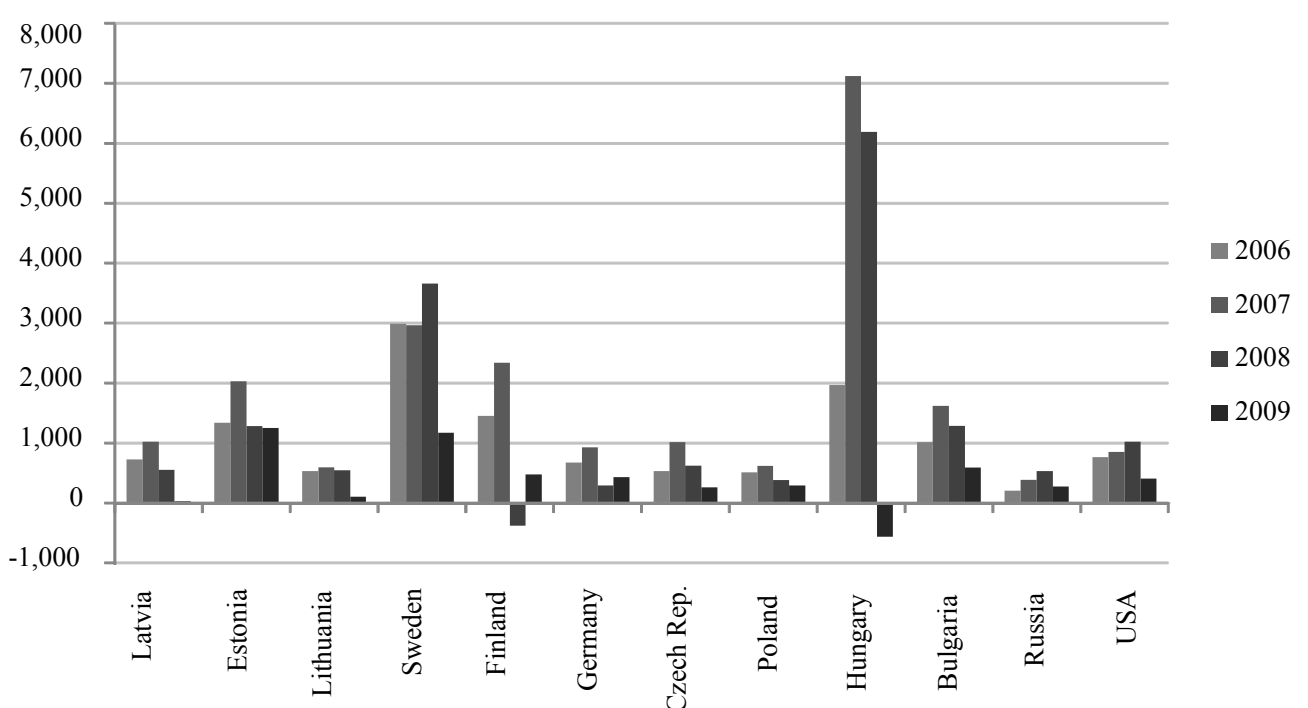

Figure 3. Net inward FDI flows in Baltic countries and other selected countries (2006-2009, USD per capita).

Source: Transparency International.

However, now in the post-crisis environment, when the state's resources for the prevention and combating corruption in many countries are limited by the fiscal consolidation measures, it is of a great importance to continue to study the influence of corruption on the economy and find solutions in limiting its impact on investment activity.

\section{Modeling and Estimating the Impact of the Host Country Corruption on Inward FDI}

To analyze if host country corruption level is really reflected in the actually received inward FDI flows, the author offers to use classical econometric kind of equation which helps to test the relationship between the variables:

$$
y_{t}=c+A X_{t}+\varepsilon_{t}
$$

where $c$-constant, $y_{t}$-dependent factor, $X_{t}$-independent factor vector, $A$-elasticity coefficient vector of independent factors and $\varepsilon_{t}$-error.

Taking into account the above mentioned necessity to assess the relationship between the corruption level and the amount of inward FDI equation (1) can be written in the following way: 


$$
F D I_{i, t}=c+\beta C P I_{i, t}+\varepsilon_{i, t}
$$

where $F D I_{i, t}-$ FDI net inward flow amount per capita in the country $i$ during period $t ; C_{i, t}-$ Corruption perceptions index in the country $i$ in period $t$ and $\varepsilon_{i, t}$ error describing shocks affecting investment activity.

To estimate the impact of corruption on FDI, the following data sources were used:

(1) UNCTAD statistical Internet data base which provides data on inward FDI flows for about 196 world countries;

(2) International agency transparency international website, which provides data on corruption perceptions index (CPI) for about 180 world countries.

For the econometric estimation of the equation (2) data on inward FDI flow amount and CPI score from the sources mentioned above for the period of time from 2004-2009 were used. Because of the fact that the data on CPI scores in 2004 are available only about 146 countries, in 2005-159 countries, in 2006-163 countries, in 2007, 2008 and 2009-180 counties, and taking into account data availability simultaneously on FDI dynamics and CPI, data about 178 countries were used. The total number of observations included in the panel is 991 .

For the estimation of panel regression the generalized least square method (pool EGLS) with cross-sectional weights was used. The estimation results of the equation (2) are revealed in the Table 1.

Table 1

Estimation Results of the Model on the Impact of the Host Country Corruption on Inward FDI

\begin{tabular}{lcccc}
\hline Variable & Coefficient & Std. error & $t$-statistic & Prob. \\
\hline$c$ & -443.814 & 21.463 & -20.678 & 0.000 \\
$C P I_{i, t}$ & 199.425 & 7.929 & 25.150 & 0.000 \\
\hline Adjusted $R$-squared & 0.389 & & & \\
Durbin-Watson stat. & 0.757 & & & \\
\hline
\end{tabular}

Note. Dependent variable: $F D I_{i, t}$. Source: Research findings.

As it can be seen from the data included in the Table 1, all equation coefficients are statistically important at the one percent level. Adjusted $R$-squared indicates that in average during the time period analyzed in the world countries included in the research $38.9 \%$ from the dependent variable $F D I_{i, t}$ variation are explained by the variation of the value of independent variable, that is, corruption perceptions index $\left(C P I_{i, t}\right)$ value.

The value of the regression coefficient obtained as the result of the estimation of the model (see equation (2)) describing the impact of CPI variation on inward FDI flow amount (see Table 1) can be interpreted as follows: decrease (increase) of host country corruption level which is reflected in the improvement (decline) of CPI score per one unit, on average results in increase (decrease) of inward FDI flow amount in the host country by 199.43 USD per capita.

The author of the paper is of opinion that it would be important to research the effect caused by corruption taking into account the specifics of the analyzable countries. One of the possible techniques here could be to group countries according to some parameters. The author offers to use UNCTAD classification of host country development level to reach the goal mentioned above. UNCTAD in its statistics traditionally divide world countries into three groups: developed countries, developing countries and transition countries. Using UNCTAD data the author has supplemented equation (2) with two dummy variables which accordingly reflect developed 
and developing countries (see equation (3)).

$$
\begin{aligned}
& F D I_{i, t}=c+\beta_{1} C P I_{i, t}+\beta_{2} \text { developed }_{i, t}+\beta_{3} \text { developing }+\beta_{4} C P I_{i, t} \times \text { developed }_{i, t}+ \\
& +\beta_{5} C P I_{i, t} \times \text { developing }_{i, t}+\varepsilon_{i, t}
\end{aligned}
$$

where $F D I_{i, t}$ net inward FDI flow amount per capita in the country $i$ during period $t, C P I_{i, t}$ Corruption perceptions index in the country $i$ in period $t$, developed, developing - dummy variables for developed and developing countries and $\varepsilon_{i, t}$-error describing shocks affecting investment activity.

Equation (3) as well as multiplications of CPI and dummies are included in order to find out whether the regression coefficient values obtained as a result of the estimation of equation (3) substantially differ for the groups of countries mentioned above. The results of the estimation of equation (3) are revealed in Table 2.

Table 2

Econometric Results of the Estimation of the Model With Dummy Variables

\begin{tabular}{lcccl}
\hline Variable & Coefficient & Std. error & $t$-statistic & Prob. \\
\hline$c$ & -141.951 & 37.199 & -3.816 & 0.000 \\
$C P I_{i, t}$ & 114.464 & 14.217 & 8.051 & 0.000 \\
developed & -198.706 & 124.043 & -1.602 & 0.101 \\
developing & -200.347 & 45.955 & -4.360 & 0.000 \\
$C P I_{i, t} \times$ developed & 96.799 & 28.179 & 3.435 & 0.001 \\
$C P I_{i, t} \times$ developing & 40.147 & 17.451 & 2.301 & 0.022 \\
\hline Adjusted $R$-squared & 0.426 & & \\
Durbin-Watson stat. & 0.793 & & \\
\hline
\end{tabular}

Note. Dependent variable: $F D I_{i, t}$. Source: Research findings.

As the result of including dummy variables in the analyzable equation, the value of adjusted $R$-squared has increased indicating that during the time period analyzed in the countries included in the research in average $42.6 \%$ from the dependent variable $F D I_{i, t}$ variation are explained by the variation of the value of independent variable, that is, corruption perceptions index $\left(C P I_{i, t}\right)$ value.

It has to be admitted that dummy variable for developed countries is statistically significant at a conventional level (ten percent level) and its multiplication with CPI is statistically significant at one percent level. On the whole it indicates that in developed countries the degree of corruption impacts on inward FDI flow which is described by $C P I_{i, t}$ coefficient (statistically important at one percent level) differs from the average level. In the group of developed countries the improvement (decline) of CPI score by one unit results on average in inward FDI amount increase (decrease) in the host country by 211.26 USD per capita ${ }^{1}$.

In its turn the dummy variable for developing countries and its multiplication with CPI are statistically significant at one and five percent level respectively (see Table 2). The respective coefficient value indicates that in the developing countries the degree of corruption impact on inward FDI flow amount is lower than in developed countries, that is, in the developing countries the improvement (decline) of CPI score by one unit results on average in increase (decrease) of inward FDI in the host country by 154.61 USD per capita. Thus, it can be concluded that in the developed countries all reforms directed to combating and prevention of corruption can

${ }^{1}$ Calculated as the sum of respective regression coefficients, i.e., $114.46+96.80=211.26$ (see Table 2). 
potentially give a bigger positive effect on foreign investor activity. The value of $C P I_{i, t}$ variable coefficient (114.46) accordingly describes the impact of corruption on inward FDI in the remaining group of countries, i.e., the transition countries.

\section{Findings and Conclusion}

Taking into account the above mentioned results and Latvia's affiliation to developed country group (according to UNCTAD classification) as well as the data on the number of inhabitants in Latvia ${ }^{2}$ it can be concluded that decrease of corruption level in Latvia which would become apparent as the improvement of CPI score by one unit would result in additional inward FDI flow in amount of about 471 mil. USD.

According to the data provided by Central Statistical Bureau of Latvia the average inward FDI amount in Latvia during the period of 2004-2009 was 587 mil. lats which converted according to the exchange rate of the Bank of Latvia ${ }^{3}$ is about 1,158 mil. USD.

Thus it can be concluded that one of the main benefits from the decrease of corruption level is quantitatively valued as an additional inward flow of the foreign capital in the economy of Latvia in the amount of about $40.7 \%$ of the average inward FDI amount during the period of 2004-2009. Thus significant inflow of foreign capital without any doubt can be regarded as a very important additional stimulus for the development of the Latvian economy.

\section{References}

Aidt, T., Dutta, J., \& Sena, V. (2008). Governance regimes, corruption and growth: Theory and evidence. Journal of Comparative Economics, 36(2), 195-220.

Choi, J. P., \& Thum, M. P. (1998). The economics of repeated extortion. Columbia University working paper, 9899-03. Retrieved May 14, 2011, from http://papers.ssrn.com/sol3/papers.cfm?abstract_id=145174

Dahlstrom, T., \& Johnson, A. (2007). Bureaucratic corruption, MNEs and FDI. Jonkoping International Business School working paper, 82. Retrieved May 14, 2011, from http://ideas.repec.org/p/hhs/cesisp/0082.html

de Mooij, R. A., \& Ederveen, S. (2001). Taxation and foreign direct investment. Netherlands Bureau for Economic Policy Analysis CPB discussion paper, 003. Retrieved May 14, 2011, from http://ideas.repec.org/p/ces/ceswps/_588.html

Dunning, J. (1981). Explaining the international direct investment position of countries: Towards a dynamic or developmental approach. Review of World Economics, 117(1), 30-64.

Hakkala, K. N., Norbäck, P. J., \& Svaleryd, H. (2005). Asymmetric effects of corruption on FDI: Evidence from Swedish multinational firms. The Research Institute of Industrial Economics IUI working paper, 641. Retrieved May 14, 2011, from http://ideas.repec.org/p/hhs/iuiwop/0641.html

Henisz, W. J. (2002). The institutional environment for multinational investment. Journal of Law and Economics and Organization, 16, 334-364.

Hines, J. R. (1995). Forbidden payment: foreign bribery and American business after 1977. NBER working papers, 5266. Retrieved May 14, 2011, from http://www.nber.org/papers/w5266

Javorcik, B. S., \& Wei, S. J. (2009). Corruption and cross-border investment in emerging markets: Firm-level evidence. Hong Kong Institute for Monetary Research working papers, 062009.

Keefer, P., \& Knack, S. (1995). Institutions and economic performance: Cross-country tests using alternative institutional measures. Economics and Politics, 7(3), 207-227.

Mauro, P. (1995). Corruption and growth. Quarterly Journal of Economics, 3, 681-712.

Mauro, P. (1996). Effects of corruption on growth, investment, and government expenditure. IMF working paper, WP/96/98.

Murphy, K. M., Shleifer, A., \& Vishny, R. W. (1991). Allocation of talent: Implications for growth. Quarterly Journal of Economics,

\footnotetext{
2 According to CSB data the total population of Latvia at the beginning of 2011 was 2,229.5 thous.

${ }^{3}$ Exchange rate as of 04.03.2011.
} 
106, 503-530.

Murphy, K. M., Shleifer, A., \& Vishny, R. W. (1993). Why is rent-seeking so costly to growth. American Economic Review, 83(2), 409-414.

Smarzynska, B. K., \& Wei, S. J. (2000). Corruption and composition of foreign direct investment: Firm-level evidence. NBER Working Papers, 7969. Retrieved May 14, 2011, from http://www.nber.org/papers/w7969

Svensson, J. (2003). Who must pay bribes and how much? Quarterly Journal of Economics, 118(1), 207-230.

Transparency International. (1992). Corruption perceptions index. Retrieved from http://www.transparency.org/policy_research/surveys_indices/cpi

Wei, S. J. (2000). Local corruption and global capital flows. Brookings Papers on Economic Activity, 2, 303-354.

Wheeler, D., \& Mody, A. (1992). International investment location decisions: The case of U.S. firms. Journal of International Economics, 33(1-2), 57-76. 